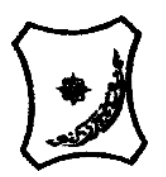

Bayero Journal of Pure and Applied Sciences, 14(1): 13 - 16

Received: February, 2021

Accepted: May, 2021

ISSN $2006-6996$

\title{
EFFECT OF AQUEOUS EXTRACT OF Irvengia gabonensis ON ACETAMINOPHEN INDUCED NEPHROTOTOXICITY IN RATS
}

\author{
Muhammad, I. U., ${ }^{1 *}$ Idi, A., ${ }^{2}$ Ibrahim, A. B. ${ }^{3}$ and Abubakar, B. M. ${ }^{1}$ \\ ${ }^{1}$ Department of Medical Biochemistry, College of Medical Sciences, Yobe State University, Damaturu, \\ P.M.B 1144; Yobe, Nigeria. \\ ${ }^{2}$ Department of Biochemistry, Faculty of Basic Medical Sciences, Bayero University Kano, P.M.B.3011, \\ Kano, Nigeria. \\ Department of Human Physiology, College of Medical Sciences, Yobe State University Damaturu, \\ P.M.B. 1144, Yobe. Nigeria \\ *Corresponding author Email:ibrahimmuhd@yahoo.com
}

\begin{abstract}
The use of medicinal plant to prevent and/or cure liver problems is a practice not peculiar to developing countries. This research work evaluated the nephrocurative ability of aqueous seed extract of Irvengia gabonensis on Acetaminophen Induced Nephrotoxicity. $A$ total of thirty albino rats were grouped into six groups (GI - GVI) of five rats each. GI served as normal control, GII served as positive control, GIII, GIV and GV were administered with the extract at a dose of $50 \mathrm{mg} / \mathrm{Kg}, 100 \mathrm{mg} / \mathrm{Kg}$ and $150 \mathrm{mg} / \mathrm{Kg}$ respectively while GVI rats were administered with standard drug (Vit E) at a dose of $10 \mathrm{mg} / \mathrm{Kg}$. Kidney damage was induced in groups (II-VI) using $800 \mathrm{mg} / \mathrm{Kg}$ of acetaminophen administered orally, rats from group I and II were euthanized24 hours after acetaminophen administration to confirm inducement of kidney damage. Groups III, IV, $V$ and VI were administered with the respective doses for two weeks. $A$ significant decrease $(p<0.05)$ in mean serum level of Urea, Potassium $\left(\mathrm{K}^{+}\right)$, Chloride $\left(\mathrm{Cl}^{-}\right)$ and Creatinine with a significant increase $(p<0.05)$ in the level of serum Sodium $\left(\mathrm{Na}^{+}\right)$ and Bicarbonate $\left(\mathrm{HCO}^{-}\right)$was observed when compared with positive control. The nephrocurative effect of the plant could be due to its reported secondary metabolites contents.
\end{abstract}

Keywords: Acetaminophen; Irvengia gabonensis; Kidney function indices and Nephrocurative.

\section{INTRODUCTION}

Medicinal plants are the back bone of traditional medicine. The use of plant preparation for treatment and prevention of ailments traditionally depends on experience and superstitious beliefs passed from generation to generation, virtually by the word of mouth (Sofowora, 1993). Researches on medicinal plants are on the increase globally. Various parts of medicinal plants (stem, bark, seeds and roots) have been used in various systems as they have potential effects against numerous diseases. Medicinal plants have been used as a source of medicine to treat/manage diseases for centuries (Sofowora, 1993).

Irvingia gabonensis, popularly known as 'ogbono' and commonly called 'African mango' or "Wild mango", is an indigenous forest tree belonging to the group of plants classified as "non-timber forest products (NTEP). It belongs to the Irvingiaceae family of plants. The tree attains a height of up to 30 meters and about 1.0 meter in girth when fully developed. The leaves are simple and alternate, up to $10 \mathrm{~cm}$ long with deciduous stipples up to $1.2 \mathrm{~cm}$ long, with leaves encircling scares on the branchlets (Matos et al., 2009)

Studies undertaken on the nutritional and medicinal value of Irvingia gabonensis have been reported and methanol extract of Irvingia gabonensis was reported to be effective in the treatment of bacterial and fungal infections. Seeds oils have extensive demands both for human consumption and for industrial applications and also have been rated as the second most valuable commodity in the world trade today. Numerous researchers, among others have carried out a lot of analytical works on seeds primarily because of extensive and increasing demands for both human consumption and numerous industrial applications (Tchoundjeu and Atangana, 2007). Traditionally, Irvingia gabonens bark is used as analgesic, antiseptic, antipyretic and also in the treatment of diarrhea and hernia, while leaf extract is used as a febrifuge and the kernels in 
BAJOPAS Volume 14 Number 1, June, 2021 the management of diabetes (Burkill, 1985; Okolo et al., 1995). Raji et al (2000) reported that methanol extract of its stem bark has antidiarrheal and antiulcer properties in rats. It has been used wholly or as supplement in the treatment of type II diabetics and in reducing obesity (Omoruyi and Adamson, 1994). Oben et a/(2008) stated that Irvingia gabonensis seed extract resulted in a significant inhibition of intracellular triglycerides.

Kidneys are organs that serve several essential regulatory roles in most animal species, including vertebrates and some invertebrates. They are essential in the urinary system and also serve homeostatic functions such as the regulation of electrolytes, maintenance of acidbase balance, and regulation of blood pressure (via maintaining salt and water balance). They serve the body as a natural filter of the blood, and remove wastes which are diverted to the urinary bladder. Nephrotoxicity is a poisonous effect of some substances notably toxic chemicals and drugs on the kidneys (Galley, 2000). It's the most common kidney problem and occurs when the body is exposed to a drug or toxin that causes damage to the kidneys. When kidneys damage occurs, the body is unable to get rid of excess urine and wastes. This cause a rise in blood electrolytes such as Potassium, Sodium, Chloride and Magnesium.

Acetaminophen is most widely used in the world as an analgesic and antipyretic drug that is safe at therapeutic dosages. However, it is also known to cause hepatic necrosis and renal failure when overdosed in humans and animals (Ghosh et al., 2010). In human, acetaminophen represents a growing cause of renal failure in current medical practice. Acetaminopheninduced renal insufficiency is consistent with acute tubular necrosis, an increase in the plasma creatinine level and a decrease in the glomerular filtration rate (GFR).

This study was aimed at determining the curative effect of aqueous seeds extract of Irvengia gabonensis on kidney function indices (Urea, electrolytes and Creatinine) on acetaminophen induced kidney damage in order to give an insight on the possible nephrocurative effects of the extract.

\section{MATERIALS AND METHODS \\ Study Animals}

Male and female Albino rats weighing $100-120 \mathrm{~g}$ were purchased from Department of Biological Sciences, Bayero University Kano. The animals were housed in colony cages at an ambient temperature $\left(30-35^{\circ} \mathrm{C}\right)$. The animals had free access to standard palletized grower feed and drinking water. Principle of laboratory animal care and ethical guidelines for investigation of experimental pain in conscious animals were observed during experimentation (NIH, 1996; Zimmermann, 1983).

\section{Collection and Extraction of the Plant Material}

Irvengia gabonensis seeds were bought from Yan lemo fruit market Zaria road Kano, Nigeria. The seeds were shade dried and ground into powder form out of which $100 \mathrm{~g}$ of the powder was weighed and soaked in $500 \mathrm{~cm} 3$ of distilled water for 24 hours. Thereafter, the solution was filtered and $10 \mathrm{~mL}$ of the filtrate was evaporated to dryness in an oven at $40^{\circ} \mathrm{C}$ to produce a dark brown residue. The residue was weighed and the concentration of the filtrate was found to be $200 \mathrm{mg} / \mathrm{mL}$. This was administered to the animals according to the required dose using the relation (Muhammad et al., 2015).

Volume to be administered $(\mathrm{cm} 3)=$ Weight of rats $(\mathrm{Kg}) \times$ dose $(\mathrm{mg} / \mathrm{Kg})$

\section{Experimental Design Induction of kidney damage}

Kidney damage was induced using acetaminophen according to the method of (Adeneye et al., 2008; Cekmen et al., 2009).

\section{Concentration of the extract $(\mathrm{mg} / \mathrm{mL})$}

Exactly $800 \mathrm{mg} / \mathrm{Kg}$ of acetaminophen was administered by single dose orally. The volume of acetaminophen administered was determined by the weight of the rat according to the following relationship (Muhammad et al., 2015).

Volume to be administered $(\mathrm{cm} 3)=$ weight of rats $(\mathrm{Kg}) \times$ dose $(\mathrm{mg} / \mathrm{Kg})$

$$
\text { Concentration of Acetaminophen }(\mathrm{mg} / \mathrm{mL})
$$

\section{Effect of aqueous seed extract of Irvengia gabonensis on acetaminophen induced Nephrotoxicity}

A total of 30 albino rats were grouped into six groups of five rats each.

Group I: Normal control; no kidney damage was induced and no extract was given
Group II: Positive control; induced with kidney damage, no extract was given

Group III: Induced with kidney damage and administered with the extract at a dose of $50 \mathrm{mg} / \mathrm{Kg}$

Group IV: Induced with kidney damage and administered with the extract at a dose of $100 \mathrm{mg} / \mathrm{Kg}$ 
BAJOPAS Volume 14 Number 1, June, 2021

Group V: Induced with kidney damage and administered with the extract at a dose of $150 \mathrm{mg} / \mathrm{Kg}$

Group VI: Induced with kidney damage and administered with Vit $E$ a dose of $10 \mathrm{mg} / \mathrm{Kg}$

The rats from group I and II were euthanized 24 hours after acetaminophen administration and blood samples were analyzed for kidney function indices to confirm inducement of kidney damage. Group III, IV, and V were administered with the respective doses of aqueous seed extract of Irvengia gabonensis and group VI with vitamin $\mathrm{E}$ for two weeks.

\section{Statistical Analysis}

Results were expressed as mean \pm standard deviation and analyzed using ANOVA, with $P$ value $<0.05$ considered significant, a component of GraphPad Instat3 Software version 3.05 by GraphPad Inc.

\section{RESULTS AND DISCUSSION}

Table 1 present the result for kidney function analysis after 24 hours of acetaminophen administration. The results shows a significant increase $(p<0.05)$ in the mean serum level of Urea, Potassium $(\mathrm{K}+)$, Chloride $\left(\mathrm{Cl}^{-}\right)$and Creatinine with a significant decrease $(p<0.05)$ in the level of serum Sodium $(\mathrm{Na}+)$ and Bicarbonate $\left(\mathrm{HCO}^{-}\right)$in Acetaminophen induced rats (Group II) compared with the control group (Group I).

Table 1. Kidney Function Indices of Rats after $\mathbf{2 4}$ hours of Acetaminophen Administration $\begin{array}{llllll}\text { Urea } & \mathrm{Na}^{+} & \mathrm{K}^{+} & \mathrm{Cl}^{-} & \mathrm{HCO}_{3}{ }^{-} & \text {Creatinine } \\ \text { MDA }\end{array}$

$\begin{array}{lllllll}(\mathrm{mg} / \mathrm{dL}) & (\mathrm{mmol} / \mathrm{L}) & (\mathrm{mmol} / \mathrm{L}) & (\mathrm{mmol} / \mathrm{L}) & (\mathrm{mmol} / \mathrm{L}) & (\mu \mathrm{mol} / \mathrm{L}) & (\mathrm{nMol} / \mathrm{L})\end{array}$

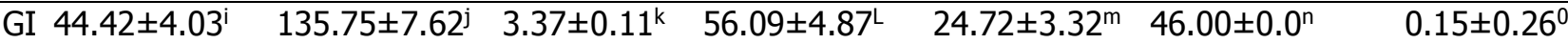

GII $146.74 \pm 6.16^{\mathrm{i}} \quad 104.67 \pm 2.54^{\mathrm{j}} \quad 6.56 \pm 0.16^{\mathrm{k}} \quad 148.78 \pm 8.79^{\mathrm{L}} \quad 11.64 \pm 0.35^{\mathrm{m}} \quad 168.67 \pm 0.56^{\mathrm{n}} \quad 0.53 \pm 0.20^{0}$

Values are presented as mean $\pm S D, n=5$. Values bearing the same superscripts in the same column are significantly different $(\mathrm{p}<0.05)$

Table 2 shows the result for kidney function analysis after two weeks administration of the extract administration. A significant decrease $(p<0.05)$ in the mean serum level of serum Urea, Potassium $(\mathrm{K}+)$, Chloride $\left(\mathrm{Cl}^{-}\right)$and Creatinine with a significant increase $(p<0.05)$ in the level of serum Sodium $(\mathrm{Na}+)$ and Bicarbonate $\left(\mathrm{HCO}^{-}\right)$was observed in a dose dependent pattern in extract administered groups compared with positive control.

Table 2. Kidney Function Indices of Rats afterTwo Weeks of Extract Administration

\begin{tabular}{|c|c|c|c|c|c|c|c|}
\hline & $\begin{array}{l}\text { Urea } \\
\text { (mg/dL) }\end{array}$ & $\begin{array}{l}\mathrm{Na}^{+} \\
(\mathrm{mmol} / \mathrm{L})\end{array}$ & $\begin{array}{l}\mathrm{K}^{+} \\
(\mathrm{mmol} / \mathrm{L})\end{array}$ & $\begin{array}{l}\mathrm{Cl}^{-} \\
(\mathrm{mmol} / \mathrm{L})\end{array}$ & $\begin{array}{l}\mathrm{HCO}_{3}^{-} \\
(\mathrm{mmol} / \mathrm{L})\end{array}$ & $\begin{array}{l}\text { Creatinine } \\
(\mu \mathrm{mol} / \mathrm{L})\end{array}$ & $\begin{array}{l}\text { MDA } \\
\text { (nMol/L) }\end{array}$ \\
\hline GI & $44.42 \pm 4.03^{a}$ & $135.75 \pm 7.62^{a}$ & $3.37 \pm 0.11^{a}$ & $56.09 \pm 4.87^{a}$ & $24.72 \pm 3.32^{\mathrm{a}}$ & $46.00 \pm 0.01^{a}$ & $0.15 \pm 0.26^{a}$ \\
\hline GII & 1 & 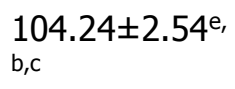 & , c,d & $\underset{c, d}{148.78 \pm 8.79^{a, b},}$ & $\begin{array}{l}11.6 \\
c, d\end{array}$ & 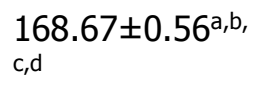 & $\begin{array}{l}0.53 \pm 0.20^{a, b}, \\
c, d\end{array}$ \\
\hline $\begin{array}{l}\text { GIII } \\
\text { GIV }\end{array}$ & $\begin{array}{l}124.54 \pm 6.17 \\
86.86 \pm 7.27^{b}\end{array}$ & & $\begin{array}{l}3.51 \pm 0.05^{\mathrm{a}} \\
2.28 \pm 0.06^{\mathrm{b}}\end{array}$ & & $\begin{array}{l}13.86 \pm 2.71 \\
15.29 \pm 0.06^{b}\end{array}$ & $\begin{array}{l} \pm 0.55^{b} \\
0.60^{c}\end{array}$ & $\begin{array}{l}0.42 \pm 0.30^{b} \\
0.26 \pm 0.26^{c}\end{array}$ \\
\hline GV & 45 & & 3.7 & & & & $2^{d}$ \\
\hline GVI & $53.87 \pm 1.17^{d}$ & $40.37 \pm 2.55^{c}$ & $2.18 \pm 0.06^{d}$ & $87.38 \pm 3.66^{d}$ & $18.64 \pm 0.42^{\mathrm{d}}$ & $47.07 \pm 2.66^{e}$ & $0.19 \pm 0.40^{\mathrm{e}}$ \\
\hline
\end{tabular}

Values are presented as mean $\pm S D, n=5$. Values bearing the same superscripts in the same column are significantly different $(\mathrm{p}<0.05)$

\section{DISCUSSION}

Acetaminophen induced renal insufficiency is consistent with hepatic necrosis and renal failure in humans and animals (Ghosh et al., 2010). About 5-15 percent of Acetaminophen is oxidized to benzoquinoneimine, a reaction catalyzed by mixed function oxidase enzyme. The benzoquinoneimine is conjugated by the glutathione pathway to form mecaptuic acid and cysteine conjugates. Oxidation occurs to a small extent after therapeutic doses and becomes more significant after large overdose (Murray et al., 2006). The benzoquinoneimine formed is conjugated to the nucleophilic GSH in a reaction catalyzed by glutathione-s-transferases which are present in high amount in the liver cytosol (Murray et al., 2006). If this potentially toxic intermediate (benzoquinoneimine) was not conjugated to $\mathrm{GSH}$, it would be free to combine with DNA, RNA and cell protein which could lead to serious cell damage. This metabolite appears to be the agent responsible for hepatic necrosis in Paracetamol overdose. It has also been postulated that increased levels of serum urea 
BAJOPAS Volume 14 Number 1, June, 2021 and creatinine are linked to kidney disease. The observed increase in serum levels of urea, potassium $\left(\mathrm{K}^{+}\right)$, chloride $\left(\mathrm{Cl}^{-}\right)$, creatinine and MDA with a significant decrease $(p<0.05)$ in bicarbonate $\left(\mathrm{HCO}^{-}\right)$and sodium $\left(\mathrm{K}^{+}\right)$in acetaminophen administered groups compared with the normal control indicates successful induction of kidney damage (Ghosh et al., 2010).

The observed a decrease in serum levels of urea, $\mathrm{K}+, \mathrm{Cl}^{-}$, creatinine and $\mathrm{MDA}$, with an increase in $\mathrm{HCO}^{-}$and $\mathrm{Na}^{+}$when compared with the test control groups may suggest the potential nephrocurative activities of the extract which may be due to its reported

\section{REFERENCES}

Adeneye A., A., Olagunju J., A., Benebo A., S., Elias, S., O., Adisa A., O., Idowu B., O. and Oyedeji M.O. (2008). Nephrocurative effects of the aqueous root extract of Harungana madagascariesnsis (L) in acute and repeated dose acetaminophen renal injured rats. IntJ. Appl. Res. Nat. Prod. 1: 6-14.

Burkill, H.M. (1985). The useful plants of west tropical Africa, Royal Botanical Gardens. Kew, United Kingdom.

Cekmen, M., Ilbey, Y., O., Ozbek, E, Simsek, A., Somay, A., Ersoz, C. (2009). Curcumin prevents oxidative renal damage induced by acetaminophen in rats. Food Chem Toxicol, 47: 1480-1484.

Galley, H. F. (2000). Can acute renal failure be prevented? J.R Coll surg Edina. 1: 44- 50.

Ghosh, J., Das, J., Manna, P. and Sil, P., C. (2010). Acetaminophen induced renal injury via oxidative stress and TNF-a production: therapeutic potential of arjunolic acid. Toxicology. 268: 8-18.

Matos, L., Nzikou, J.M., Matouba, E.V., PandzouYembe, N., Linder, T.M. and Desobry, S. (2009). Studies of Irvingia gabonensis Seed Kernels: Oil Technological Applications ENSP-UMNG, Laboratoire de Physico-chimie et de Biotechnologie Alimentaires. Pakistan Journal of Nutrition. 8 (2): 151-57

Muhammad, I.U., Alhassan, A.J., Wudil, A.M. and Jarumi, I.K. (2015). Toxicological and Protective Effect of Aqueous Stem Bark Extract of Khaya senegalensis (ASBEKS) on Liver of Experimental Rat. British Journal of Applied Science \& Technology. 9(6): 600-605.

Murray, R.K., Granner, D.K. and Rochwell, V.W. (2006). Harpers Illustrated Biochemistry. $27^{\text {th }}$ edition. McGraw Hill Lange companies Inc., Singapore. Pg. 204-205, 634-638. phytochemicals (tannins, alkaloids, glycoside, flavonoids and terpenoids) constituent of the plant. A possible mechanism for the nephrocuration may be due to their antioxidant properties, which could counteract the toxic effect of benzoquinoneimine produced through Paracetamol metabolism (Tomaet al., 2009).

\section{CONCLUSION}

The results of the present study showed Irvengia gabonensis seed extract to poses nephrocurative effects against acetaminophen induced kidney damage which may be mediated through its antioxidant ability.

NIH. Guidelines for the care and use of laboratory animals. (1996). National Academic Press, (NIH Publication No. 85:23.

Oben, J.E, Ngondi, J.L. and Blum, K. (2008). Inhibition of Irvingia gabonensis seed extract (OB131) on adipogenesis as mediated via down regulation of the PPAR gamma and Leptin genes and upregulation of the adiponectin gene. Lipids in Health and Disease. 4: 12.

Okolo, C.O., Johnson, P.B., Abdurahman E.M., Abdu-Aguye, I. and Husain, I.M. (1995). Analgesic effect of Irvingia gabonensis stem bark extract. Journal of Ethnopharmacology 45: 125-29.

Omoruyi, F.O. and Adamson, I. (1994). Effect of Dika nut (Irvingia gabonensis) and cellulose on plasma Lipid in streptozotocin induced diabetic rat. Nutrition Research. 14: 537-44.

Raji, Y., Ogunnwande, I.A., Adesola, J.M., Bolarinwa, A.F. (2001). Antidiarrhegenic and antiulcer properties of I. gabonensis in rats. Pharmaceutical Biology. 39(5): 34045.

Sofowora, A. (1993).Medicinal Plants and Medicine in Afric.John Willey Spectrum, IbadanNigeria. 2: $81-85$.

Tchoundjeu Z. and Atangana A.R. (2007). Irvingia gabonensis (Aubry-Lecomte ex O'Rorke) Baill. In: van der Vossen, H.A.M. \& Mkamilo, G.S. (Editors). PROTA 14: Vegetable oils/Oléagineux. [CD- Rom]. PROTA, Wageningen, Netherlands.

Toma I., Karumi Y., and Geidam M., A. (2009). Phytochemical screening and toxicity studies of the aqueous extract of the pods pulp of Cassia sieberiana D.C. African Journal of Pure and Applied Chemistry.3(2): 026-030

Zimmermann, M. (1983). Ethical guidelines for investigation of experimental pain in conscious animals. Pain.19:109-110. 